nikoli silou, ale častým dopadáním (gutta cavat lapidem non vi, sed saepe cadendo, citát z Ovidiových Epistulae ex Ponto). Snad je tu zajímavé i to, co výzkumný tým považuje ze "zlatého věku“ ruské literatury z hlediska textologie a geneze textu za stěžejní: stálicí jsou Puškin a Gogol, méně Dostojevskij, nejsou tu však ani Čechov nebo Turgeněv, ale hlavně tu jsou zastoupeni L. N. Tolstoj a N.S. Leskov - to je zajímavý, ale možná ne zcela záměrný, snad spíše náhodný posun.

Ivo Pospíšil

\title{
Bibliografie:
}

N.S.Leskov, L.N. Tolstoj.Perepiska. <http://az.lib.ru/t/tolstoj_lew_nikolaewich/text_ 0340.shtml.> [online]. [cit. 23. 8. 2020].

POSPÍŠIL, I. (ed.). (2018): Leskov i vokrug. Konteksty tvorčestva i sostojanije sovremennogo leskovovedenija. Brno.

POSPÍŠIL, I. (2020a): Ad fontes: geneze literárního textu jako svébytný návrat $k$ filologii. Philologia Rossica. 〈V tisku.

POSPÍŠIL, I. (ed.). (202ob): N. S. Leskov i tradicija russkogo romana v mirovom kontekste. Brno.

REMIZOV, V. B. (2020): Tolstoj i russkaja literatura. <https://www.tsput.ru/res/other/ Tolstoy/Literature/leskov.htm.> [online]. [cit. 23. 8. 2020].

ŠČERBAKOVA, M. I. (red.). (2015): Ot istorii teksta $k$ istorii literatury. Moskva.

ŠČERBAKOVA, M. I. (red.). (2019): Ot istorii teksta k istorii literatury. Moskva.

https://doi.org/10.5817/NR2020-2-9

\section{Когда слова могут оказаться нашими врагами...}

GRIGORJANOVÁ, T., GAJARSKÝ, L.: Slovník rusko-slovenských medzijazykových homoným. Brno: Tribun EU, 2019. 126 s. ISBN 978-80-263-1544-5.

Межъязыковые омонимы опасны не только для переводчиков, но и для всех изучающих иностранные языки. В основном это явление наблюдается в близкородственных языках. Каждый, кто изучал или изучает такой язык, наверное, попадал в ситуацию, когда что-то неправильно понял из-за сходства слов. Ему либо не хотелось искать перевод, либо просто у него не было доступа к словарю, чтобы узнать значение слова. Такие ситуации чаще всего бывают смешными, но иногда могут оказаться весьма неприятными или 
конфузными. Помочь избежать таких неловких моментов может Словарь русско-словациких межъязыковых омонимов. Он является превосходной и уникальной публикацией не только потому, что это вообще первый русско-словацкий словарь, отражающий проблематику межъязыковых омонимов, но и потому, что он написан очень понятно и ясно, благодаря чему в нем можно легко ориентироваться. Таким образом, словарем могут пользоваться не только переводчики и специалисты, но и люди, которые изучают язык или желают пополнить свои знания.

Словарь возник по инициативе Татьяны Григоряновой и нескольких студентов, приложивших усилия для сбора материала и создания этой публикации. Татьяна Григорянова - лингвист, официальный переводчик и в настоящее время - преподаватель на кафедре романских и славянских языков факультета прикладных языков Экономического университета в Братиславе. Долгое время она руководила кафедрой русистики Университета свв. Кирилла и Мефодия в Трнаве, которую также основала. В то время и возникла идея создать словарь, посвященный межъязыковой омонимии. Соавтором словаря является Лукаш Гаярски, который в начале создания словаря входил в число студентов. А позже, уже как преподаватель университета, упорядочил весь собранный материал, благодаря чему словарь приобрел конечную форму. Лукаш Гаярски является активным членом кафедры русистики философского факультета Университета имени свв. Кирилла и Мефодия в Трнаве. Он также, как и доцент Григорянова, является лингвистом. Это свидетельствует о том, что данная публикация была создана настоящими профессионалами в этой области.

В самом начале словаря дается объяснение по каким критериям были собраны слова, в том числе и примеры. Авторы подбирали не только слова, которые пишутся одинаково, но и слова подобные по своему звучанию или написанию. Такое «сходство» слов в двух языках, как отмечают авторы, может приводить к недоразумению в коммуникации и неправильному переводу. Поэтому их можно называть «ложными друзьями переводчика».

Словарь русско-словацких межъязыковых омонимов составлен в азбучном порядке, так как исходным языком является русский. Он также очень нагляден, благодаря списку слов с указанием страницы, на которой его можно найти. В самой словарной статье каждое слово объясняется в отдельной таблице, где, кроме перевода, есть и его применение в словосочетании и предложении. Авторы также замечают, что у некоторых слов можно обнаружить одинаковые значения в обоих языках, но в словаре они не рассматриваются, потому что в центре внимания слова, являющиеся омонимами.

Как уже было сказано выше, словарь является уникальным изданием, которое направлено устранить недоразумения в коммуникации между русскими 
и словаками. Данный словарь адресован не только словацким студентам и переводчикам, но и русским, изучающим или работающим со словацким языком. Словарь русско-словацких межъязыковых омонимов должен быть у каждого студента, переводчика и любителя этих двух языков.

Zina Špačeková

\section{Библиография:}

GRIGORJANOVÁ, T., GAJARSKÝ, L. (2019): Slovník rusko-slovenských medzijazykových homoným. Brno. 